\title{
Plant Pathology
}

http:/www.journals.zu.edu.eg/journalDisplay.aspx?Journalld=1\&queryType=Master

\section{BIO-CONTROL OF POTATO BACTERIAL WILT CAUSED BY Ralstonia solanacearum ISOLATED FROM DIFFERENT SOURCES}

\author{
Shadia A. Abd-El-Aziz ${ }^{1 *}$, Iman M. El-Azouni ${ }^{2}$ and Amira G. Rabea ${ }^{1}$ \\ 1. Pl. Pathol. Res. Inst., Agric. Res. Cent., Giza, Egypt \\ 2. Bot. Dept., Fac. Sci., Zagazig Univ., Zagazig, Egypt
}

Received: 15/05/2017 ; Accepted: 22/08/2017

\begin{abstract}
Seventeen pathogenic isolates of brown rot pathogen were collected from field soil, potato tubers, weeds and irrigation water at major potato districts in Egypt. Isolates recovered produced pink, or light red, colour with whitish margin on tetrazolium chloride medium (TZC) indicated possible virulent Ralstonia solanacearum pathogenic isolates. Pathogenicity test revealed the ability of the isolates to cause wilt symptoms in potted potato plant and three leaved tomato seedlings. Morphological, physiological and biochemical tests were used in identification. The biovar determination was made using for oxidization of disaccharides (maltose, lactose, and cellobiose) and confirmed the identity to $R$. solanacearum, race 3, biovar II equivalent to phylotype II, sequevar 1 . A polymerase chain reaction (PCR) confirmed the identity of highest virulent isolates from tuber (T6) and from water (W11) to $R$. solanacearum. The application of biological agents Pseudomonas fluorescens, Bacillus subtilis, Pseudomonas aeruginosa and Trichoderma spp. decreased R. solanacearum infected plants and caused greater decrease in severity.
\end{abstract}

Key words: Ralstonia solanacearum, race 3, biovar II, phylotype II, sequevar 1, brown rot, potato, identification, PCR, biological control.

\section{INTRODUCTION}

Brown rot is the second most important potato disease in tropical and sub-tropical regions of the world after late blight (Champoiseau et al., 2010). The pathogen nomenclature was changed successively from time to time ended by $R$. solanacearum named by Yabuuchi et al. (1995). A soil-borne Gramnegative bacterium is a recognized parasite in over 200 families of plants, including potato, brinjal and tomato as well as many native plant species (Ahmed et al., 2013).

The brown rot disease was recorded on potato in Egypt and the bacterium was isolated for the first time in Egypt from potato tubers showing rot symptoms (Sabet, 1961) and extended to El-Habbaa et al. (2016) who reported the isolation from naturally infected potato tubers of three potato cultivars and bacteria showed

\footnotetext{
*Corresponding author: Tel.: +201066489302

E-mail address: shadia21@yahoo.com
}

typical morphology for $R$. solanacearum on SMSA medium (Balabel, 2006). Identification of the isolated bacteria were non-sporulating short rods with weak Gram negative reaction. Also, their developed colonies on nutrient agar (NA) medium were irregularly/round, convex, smooth surface, entire margin, translucent and yellowish brown in colour (Holt et al., 1994). The colonies were whitish-gray in colour on King's B (KB) medium forming brown pigments in most cases.

$R$. solanacearum has already been classified into five races based on differences in host range and six biovars on the basis of biochemical properties according to carbon source utilization (Hayward, 1991; Tohamy et al., 2007; Ahmed et al., 2013).

Pastrik et al. (2002) used PCR technique as one of rapid, highly specific and sensitive tests for detection and identification of $R$. solanacearum which isolated from different sources. In 
practice sensitivity of PCR reaction depends upon recovery of target DNA sequence and efficiency of the PCR reaction (Grover et al., 2012).

Biological control is supposed to preserves environmental quality by minimizing dependency on chemical inputs and maintaining sustainable management practices (Barea and Jeffries, 1995). Soesanto et al. (2013) reported the successful antagonistic Bacillus sp. and Pseudomonas fluorescens isolated from rhizosphere to control bactrial wilt on potato with delaying incubation period, suppressing disease intensity, decreasing final pathogenic population and inducing plant resistance. Atia et al. (2010) found that, the application of Bacillus sp., B. subtilis and P. fluorescens effectively controlled brown rot pathogen and increased potato yield ( $\mathrm{g} / \mathrm{plant}$ ).

This research work aimed to survey Ralstonia solanacearum the causative agent of brown rot at different localities in Egypt as well as controlling the disease using some bioagents.

\section{MATERIALS AND METHODS}

\section{Collection of Samples}

One hundred and forty samples were collected from field soils, infected tubers, irrigation water and weeds (Table 1).

\section{Isolation of the Pathogen}

Potato tubers were washed in running tap water, surface sterilized by flaming. Then sections from stolen end were macerated in 10 $\mathrm{ml}$ sterile phosphate buffer $(\mathrm{pH}$ 7.0) in sterile plastic bags. The macerated tissues were allowed to stand for 30 minutes and the obtained suspension was used to inoculate plates of Semi Selective South Africa (SMSA) medium as described by Engelbrecht (1994) and modified by Elphinstone et al. (1996). Incubation was done at $28^{\circ} \mathrm{C}$ and observed daily for developing fluidal, slightly raised, irregular white or white pinkish center colonies, typical for virulent colonies of $R$. solanacearum. Resulted virulent colonies were selected, picked up and inoculated on glucose nutrient agar medium and incubated for $48 \mathrm{hr}$., at $28^{\circ} \mathrm{C}$ (Schaad, 1980).
Water samples $(50 \mathrm{ml} / \mathrm{sample})$ were labeled, placed in an ice box and directly transferred to the laboratory. Samples collected from each site were centrifuged at $10,000 \mathrm{rpm}$ for 15 minutes at $15^{\circ} \mathrm{C}$. The supernatant was discarded and pellet was re-suspended in one $\mathrm{ml}$ of phosphate buffer ( $\mathrm{pH}$ 7.2), vortex for homogenization and plated on SMSA plates. Observation for the colonies growth was carried out as previously mentioned in isolation from potato tuber.

Soil samples $(100 \mathrm{~g})$ from each location as mentioned in collectio of sample were taken and mixed in the laboratory for homogenization. Isolation of the brown rot pathogen from soil was made on SMSA medium according to the method described by Van der Wolf et al. (1998).

Decimal dilutions of soil suspension obtained was made in $90 \mathrm{ml}$ sterile phosphate buffer $(\mathrm{pH}$ 7.0) to $10^{-6}$, shacked for two hours at $15^{\circ} \mathrm{C}$ and inoculate SMSA plates incubated at $28^{\circ} \mathrm{C}$ and observation for the colonies growth was carried out as previously mentioned.

Different weed plants associated with potato crop were collected. Roots were washed in running tap water and surface sterilized by flaming. Sterilized roots were aseptically cut into $5-10 \mathrm{~mm}$ sections, containing the main vascular and cortical tissues, were macerated in $10 \mathrm{ml}$ sterile phosphate buffer $(\mathrm{pH} \mathrm{7.0)}$ and were allowed to stand for 30 minutes before use.

Plating of the resulting supernatant and suspensions were streaked on Semi Selective South Africa (SMSA) medium selective for the pathogen as described by Wenneker et al. (1999).

\section{Pathogenicity Test}

Pathogenicity tests were conducted in greenhouse of Botany Department, Faculty of Science, Zagazig University. Seventeen $R$. solanacearum isolates recovered from different habitats and exhibited virulent morphology were confirmed by inoculation. Two weeks old healthy three leaved seedlings of GS12 tomato cultivars potted in $10 \mathrm{~cm}$ diameter plastic pots with sandy-clay soil $(1 / 1, V / V)$ and Nicola potato plants grown in $30 \mathrm{~cm}$ diameter plastic pots containing sandy-clay soil. Inoculation with $10^{7} \mathrm{cfu} / \mathrm{ml}$ was done by stem puncture technique described by Janse (1988). Similarly, controls were carried out using sterile water instead of 
bacteria. Three pots as replicates were used for each isolate. The inoculated plants were covered with polyethylene bags for three days, at $30^{\circ} \mathrm{C}$ to maintain high relative humidity, then the bags were removed and pots were irrigated regularly till the end of experiment (Algam et al., 2010). The disease progress was determined according to the key proposed for describing the wilt as follows: $1=$ no symptoms; $2=1-25 \%$ of the plant was wilted; $3=26-50 \%$ of the plant was wilted; $4=51-75 \%$ of the plant was wilted and 5 $=$ more than $75 \%$ of the plant was wilted. The disease severity was calculated by using the formula as disease index (\%) (Kemp and Sequeira, 1983) as given below:

DI $($ disease index $)=$

$\frac{\left.\sum \text { (No. of wilted plants in treatment } \times \text { wilt grade }\right)}{\text { Total No of plants } \times \text { highest grade }} \times 100$

According to Koch's postulates, the inoculated bacteria were re-isolated from plants with typical wilt symptoms of the disease and the most pathogenic isolates were selected for the following tests. These isolates included soil isolates (S1, S2, S3 and S4), tuber isolates (T5, T6, T7, T8 and T9), water isolates (W10, W11, $\mathrm{W} 12, \mathrm{~W} 13$ and W14) and weed isolates (We15, We16 and We17).

\section{Identification of the Pathogen}

Morphological and biochemical studies were carried out according to Bergy's Manual of Determinative Bacteriology (Holt et al., 1994; George and Garrity, 2012).

Morphological characteristics of isolated bacteria was done on King's B and TZC (Denny, 2006) and SMSA medium according to Engelbrecht (1994) and modified by Elphinstone et al. (1996).

The bacterial biochemical identification including pigmentation on KB medium, Gram stain, oxidase, catalase test, starch hydrolysis, gelatin liquefaction, lecithin hydrolysis, denitrification, casein hydrolysis, urea hydrolysis, growth in $\mathrm{KCN}$, citrate utilization as $\mathrm{C}$ source, arginine dihydrolase, Levan formation, growth in $\mathrm{KOH} \mathrm{3 \%}$, indol production and oxidation were carried out according to Koneman et al. (1983).
The isolates of $R$. solanacearum were differentiated into biovars based on their ability to utilize glucose and disaccharides (cellobiose, lactose, maltose) and sugar alcohols (manitol, sorbitol) as described by Hayward (1964).

The races of $R$. solanacearum were identified by pathogenicity test on host range. Identification of $R$. solanacearum isolates was confirmed using polymerase chain reaction (PCR) techniques according to Pastrik et al. (2002). The PCR assay was conducted at Potato Brown Rot Project, Agric. Res. Cent., Giza, Egypt.

A specific olignucleotide primers are used, the forward oligonuclutide primer RS-1-F (5'ACT AAC GAA GCA GAG ATG CAT TA $\left.3^{\prime}\right)$ and the reverse Primer RS-1-R, (5- 'CCC AGT CAC GGC AGA GACT-3'). (Pastrik et al., 2002). The expected amplicon size from Ralstonia solanacearum template DNA is 718 bp. under the following reaction conditions:

\section{Extraction of DNA}

Crude DNA of $R$. solanacearum investigated in two isolates previously isolated from water and tuber (W11) and (T6) which proved to be virulent causing the highest disease severity, were extracted by heating $100 \mu \mathrm{l}$ aliquots of cell suspension $\left(10^{6} \mathrm{CFU} / \mathrm{ml}\right)$ to $100^{\circ} \mathrm{C}$ for 5 minutes followed by cooled rapidly on ice.

\section{DNA amplification}

From each isolate $2 \mu \mathrm{l}$ were added to $23 \mu \mathrm{l}$ reaction mixtures [(16.025 $\mu$ l, Sterile Ultra Pure Water (SUPW); $2.5 \mu 1$ of 10X PCR buffer; 1.5 $\mu \mathrm{l} \mathrm{MgCl}_{2} ; 0.25 \mu \mathrm{l}$ of BSA (fraction V) $(10 \%)$; $0.125 \mu \mathrm{l}$ d-Ntp mix; $0.5 \mu \mathrm{l}$ primer Ps- $1 ; .5 \mu$ primer Ps-2, and $0.1 \mu \mathrm{l}$ Taq polymerase)]. Different PCR cycles were performed (1 cycle of $5 \mathrm{~min}$ at $95^{\circ} \mathrm{C} ; 35$ cycles of $30 \mathrm{sec}$ at $68^{\circ} \mathrm{C}$., 45 se. at $72^{\circ} \mathrm{C}$ and; final cycle at 72 of $5 \mathrm{~min}$ (Pastrik et al., 2002).

\section{Analysis of the PCR production}

PCR fragments were detected by using agarose gel electrophoresis (AGE) and stained with ethidium bromide. Agarose gel was prepared by gently bringing agarose to the boiling $1 \mathrm{X}$ tris acetate EDTA (TAE) buffer (Seal et al., 1993). Agarose in TAE buffer was boiled for $5 \mathrm{~min}$ then cooled to $50-60^{\circ} \mathrm{C}$. 
Twenty wells were made in gel at $10-15 \mathrm{~mm}$ from the edge comb and the sealing tape was removed, the tray was placed in a large electrophoresis tank containing (1X) TAE buffer to a depth of at least $5 \mathrm{~mm}$ buffer above the gel. Three microleter droplets of loading buffer on parafilm were added to $12 \mu \mathrm{l}$ of the PCR product from either sample. The positive control and distilled water as negative controls were mixed gently then loaded into the wells of the gel. An appropriate DNA marker was included as reference in at least one well. Gel was run by applying 80 voltages $(\mathrm{V})$ at $400 \mathrm{~mA}(8 \mathrm{v} / 1 \mathrm{~cm})$ until the front of tracking indicator being within one $\mathrm{cm}$ from the end then the power supply was switched off. Gel was removed carefully and soaked in the eithidium bromide solution $(0.5 \mu \mathrm{g}$ per L) for 30-45 min. A specific PCR product of $718 \mathrm{bp} \quad \mathrm{w}$ as visualized under UV transillumination at $355 \mathrm{~nm}$ (Pastrik et al., 2002).

\section{Effect of Bio-control Agents on Potato Bacterial Wilt}

Isolates of Bacillus subtilis, Pseudomonas fluorescensa and Pseudomonas aeruginosa were kindly obtained from Plant Pathology Department, Faculty of Agriculture, Benha University, Egypt. Tichoderma sp. were kindly provided from Botany Department, Faculty of Science, Zagazig University.

\section{Tubers}

Tubers of three potato cultivars (Nicola, Mustang and Orchestra cvs.) were kindly provided by the Potato Brown Rot Project (PBRP), Dokki, Giza, Egypt.

\section{Soil}

Soil mixture was prepared at the ratio of $1: 1$ from clay and sandy soil collected from AboHammad district, El-Sharkia Governorate, Egypt.

\section{Preparation of Bio-control Organisms and Ralstonia Solanacearum Pathogen}

The antagonists bacteria were prepared by culturing on King's B broth liquid at $150 \mathrm{rpm}$ on rotary shaker, then incubated at $30^{\circ} \mathrm{C}$ for 48 hours and Czapek's broth at $150 \mathrm{rpm}$ on rotary shaker for antagonistic fungi and incubated at $28^{\circ} \mathrm{C}$ for 5 days. The pathogen was prepared by culturing on King's B broth at $150 \mathrm{rpm}$ on rotary shaker as well. Cultures were centrifuged at $10,000 \mathrm{rpm}$ under cool $10^{\circ} \mathrm{C}$ for $10 \mathrm{~min}$ and the sediment was suspended in sterile buffer and adjusted to reach concentration of $10^{8} \mathrm{cfu} / \mathrm{ml}$ at OD 600 for bacterial antagonists and $10^{7}$ spore/ $\mathrm{ml}$ for fungal one. (Nurbaya et al., 2011).

\section{Experiment}

The experiment was conducted with completely randomized block design with three replications and 1 tuber per pot. Five kilogram of soil mixture was filled into pots, each $35 \mathrm{~cm}$ in diameter (Naser et al., 2008). The experiment conducted under greenhouse condition with:

1. The control; three control (s) were prepared

$$
\begin{aligned}
& \text { Plant + bio-agent (+ve control), } \\
& \text { Plant (-ve control), } \\
& \text { Plant + R. solanacearum (control pathogen). }
\end{aligned}
$$

2. Three application tome i.e., before, after and at the time of planting.

3. Two isolates of the pathogen; $R$. solanacearum W11 from water and T6 from tubers.

4. Biological control agents were tested individually with $P$. fluorescens, B. subtilis, $P$. aeruginosa and Trichoderma sp.

\section{Experimental Infestation}

Soil infestation was made at a rate of $150 \mathrm{ml}$ of either adjusted suspention (s) $R$. solanacearum and adjusted antagonistic microbe through soil drenching (Sulistyo et al., 2012). The Pot treatments were divided into three groups:

In pot experiment I, the antagonists were introduced one week before planting and two weeks before pathogen inoculation.

In pot experiment II, the antagonists were applied one week after planting and two weeks after pathogen in this inoculation method, soils in pots were made to be fully infested with the $R$. solanacearum.

In pot experiment III, both antagonists and pathogen were introduced at the same time of planting. Each of the four antagonist suspensions was mixed separately with pathogen suspension in a screwed cap bottle equally, and after one hour, inoculated in the pots filled with planted soil. 
Plants were kept in the greenhouse during the growing period at $24-28^{\circ}$ and $75-90 \%$ relative humidity in $12 \mathrm{hr}$., light and $12 \mathrm{hr}$, dark conditions. All the pots were regularly irrigated throughout the growth periods.

\section{Data Collection}

Wilt incidence or disease index (\%), percent survival or disease reduction (\%) were recorded 85 days after planting.

The disease severity was calculated as mentioned in pathogenicity test.

\section{Statistical Analysis}

Data were subject to analyse of variance (ANOVA) according to Cochran and Cox (1957). ANOVA was carried out using IBM compatible computer using basic language. LSD test was used to compare treatments means at a 0.05 level of significance.

\section{RESULTS AND DISCUSSION}

\section{Pathogen Isolation}

A total of one hundred and forty isolates were isolated from the wilted potato tubers, irrigation waters, field's soil and weeds from different localities of Egypt during seasons of 2010 and 2011.

Total viable counts $(\mathrm{CFU} / \mathrm{ml})$ is shown in Table 1. The highest bacterial count $\left(8.53 \times 10^{8}\right.$ $\mathrm{CFU} / \mathrm{ml}$ ) was detected in tuber samples of ElGharbia and the lowest count $\left(3.53 \times 10^{3} \mathrm{CFU} /\right.$ $\mathrm{ml}$ ) was recorded in soil samples collected from El-Dakahlia Governorate. Results demonstrated that Ismailia Governorate was almost free from the disease at the time of testing. The results showed that the selected isolates revealed the incidence of the disease in the territories surveyed and then underwent pathogenicity from the isolates. These results are similar to those reported by Saad (2011).

\section{Pathogenicity Tests}

Pathogenicity tests of the selected seventeen isolates were carried out under the greenhouse condition on tomato seedlings and potato plant (Table 2).
Results indicated that plants inoculated with the isolated pathogen were highly virulent and induced complete wilting at 20 to 23 days after inoculation. Tomato seedlings and potato plants showed disease symptoms within a short period after inoculation. After plant emergence, it took approximately two to three weeks for symptoms development (Jenkins et al., 1967). Disease severity was more in potato plants than tomato seedlings. The pathogen induced $36.4-100.0 \%$ wilting in potato compared to $18.7-87.3 \%$ wilt in tomato seedlings at the same period.

Soil isolates of $R$. solanacearum showed the lowest wilt symptoms and less virulence. On contrary, the plants inoculated with water isolates were the highest, causing 100.0- 72.3\% and $84.1-48.2 \%$ wilt in potato and tomato, respectively. The highest severity of the disease was recorded with isolates coded T6 and W11, followed by T8, W12 and W14, and then T5, T9 and W10 isolates. Meanwhile, all isolates recorded positive results when reisolated on TZC medium. Similar results of isolated $R$. solanacearum from different sources were reported by Janse (1988) and Tohamy et al. (2007), Abd-Elrahim et al. (2015) and ElHabbaa et al. (2016).

\section{Identification of the Isolated Pathogenic Bacteria}

The macroscopic and the microscopic examination of the selected seventeen isolates, from different sources, were performed (Table 3 and Figs. 1 and 2). Microscopic studies revealed that bacterial isolates were gramnegative, rod-shaped, $0.5-0.7 \times 1.5-2.0 \mu \mathrm{m}$ in size non-capsulated and non-spore forming. Motility of each isolate was confirmed by performing hanging drop method (Table 3). Fig. 1 showed that florescent pigment is not produced on King's B medium. All isolates produced a brown pigment when grown on King's B medium after 72 hr., (Fig. 2) similar results were obtained by El-Habbaa et al. (2016). Typical colony characters of virulent $R$. solanacearum isolates were presented in Fig. 3. They produced typically fluid, irregular white colonies with reddish-pink centers on TZC medium. The same results were obtained by Engelbrecht (1994). 
Table 1. The counts (CFU/ml) of Ralstonia solanacearum isolated from different sources and different localities in Egypt

\begin{tabular}{|c|c|c|c|c|c|c|}
\hline \multirow[t]{2}{*}{ Governorate } & \multirow[t]{2}{*}{ Region } & \multirow{2}{*}{$\begin{array}{c}\text { No. of } \\
\text { samples }\end{array}$} & \multicolumn{4}{|c|}{ Source of isolates } \\
\hline & & & Soil & Tuber & Water & Weeds \\
\hline \multirow{3}{*}{ Sharkia } & El-Salhia city & 16 & - & $3.82 \times 10^{4}$ & - & - \\
\hline & El-Molak village & 9 & - & - & - & - \\
\hline & Ismailia canal & 12 & - & - & - & - \\
\hline \multirow{2}{*}{ Ismailia } & Ismailia city & 11 & - & - & - & - \\
\hline & Ismailia canal & 7 & - & - & - & - \\
\hline \multirow{3}{*}{ Gharbia } & Kafr Yakoupe village & 10 & - & $\begin{array}{l}8.53 \times 10^{8} \\
5.68 \times 10^{6}\end{array}$ & - & - \\
\hline & Kafr El-Zayat & 12 & - & $\begin{array}{l}6.78 \times 10^{3} \\
3.77 \times 10^{4}\end{array}$ & - & - \\
\hline & Kafr Yakoupe water stream & 14 & - & 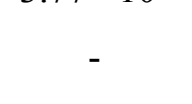 & $\begin{array}{l}6.78 \times 10^{7} \\
4.18 \times 10^{5}\end{array}$ & - \\
\hline \multirow[b]{2}{*}{ Monufia } & Tallia village & 20 & $\begin{array}{l}6.76 \times 10^{7} \\
5.32 \times 10^{5}\end{array}$ & - & - & $\begin{array}{l}7.71 \times 10^{8} \\
2.65 \times 10^{4} \\
3.55 \times 10^{3}\end{array}$ \\
\hline & $\begin{array}{c}\text { Tallia village water stream } \\
\text { and El-Basha }\end{array}$ & 17 & - & - & $\begin{array}{l}6.55 \times 10^{5} \\
4.67 \times 10^{8} \\
3.87 \times 10^{7}\end{array}$ & $6.08=10$ \\
\hline Dakahlia & Kotama village & 12 & $\begin{array}{l}3.59 \times 10^{4} \\
3.53 \times 10^{3}\end{array}$ & - & 年 & - \\
\hline
\end{tabular}

$\mathrm{CFU} / \mathrm{ml}=$ Number of colony forming units in $\mathrm{ml}$ - = Negative result.

Table 2. Pathogenicity tests of Ralstonia solanacearum isolates on tomato seedlings and potato plants

\begin{tabular}{|c|c|c|c|c|c|c|c|}
\hline \multicolumn{2}{|c|}{ Isolate source } & \multicolumn{6}{|c|}{ Severity of disease } \\
\hline & & \multicolumn{3}{|c|}{$\begin{array}{l}\text { Tomato seedlings } \\
\end{array}$} & \multicolumn{3}{|c|}{ Potato plants } \\
\hline & & $\begin{array}{l}\text { Severity } \\
\text { group }\end{array}$ & $\begin{array}{c}\text { Disease } \\
\text { severity }(\%)\end{array}$ & Re-isolation & $\begin{array}{l}\text { Severity } \\
\text { group }\end{array}$ & $\begin{array}{c}\text { Disease } \\
\text { severity }(\%)\end{array}$ & Re-isolation \\
\hline \multirow[t]{4}{*}{$\overline{\text { Soil }}$} & S1 & 2 & 27.8 & + & 2 & 36.4 & + \\
\hline & S2 & 2 & 30.6 & + & 3 & 42.3 & + \\
\hline & S3 & 2 & 18.7 & + & 2 & 36.7 & + \\
\hline & S4 & 2 & 30.1 & + & 3 & 49.8 & + \\
\hline \multirow[t]{5}{*}{ Tuber } & T5 & 3 & 51.4 & + & 3 & 67.6 & + \\
\hline & T6 & 5 & 87.3 & + & 5 & 100.0 & + \\
\hline & T7 & 2 & 33.4 & + & 3 & 72.7 & + \\
\hline & T8 & 4 & 79.4 & + & 5 & 89.8 & + \\
\hline & T9 & 3 & 57.4 & + & 4 & 79.6 & + \\
\hline \multirow[t]{5}{*}{ Water } & W10 & 3 & 55.7 & + & 4 & 80.4 & + \\
\hline & W11 & 5 & 84.1 & + & 5 & 100.0 & + \\
\hline & W12 & 4 & 73.8 & + & 4 & 85.9 & + \\
\hline & W13 & 2 & 48.2 & + & 3 & 72.3 & + \\
\hline & W14 & 4 & 74.0 & + & 5 & 89.7 & + \\
\hline \multirow[t]{3}{*}{ Weed } & We15 & 2 & 45.0 & + & 3 & 54.0 & + \\
\hline & We16 & 2 & 43.0 & + & 3 & 51.4 & + \\
\hline & We17 & 2 & 32.9 & + & 2 & 41.7 & + \\
\hline
\end{tabular}


Zagazig J. Agric. Res., Vol. 44 No. (5) 2017

Table 3. Macroscopic and examination of recovered isolates

\begin{tabular}{lcccc}
\hline Character & \multicolumn{4}{c}{ Source of bacterial isolates } \\
\cline { 2 - 5 } & Soil isolates & Tuber isolates & Water isolates & Weeed isolates \\
& $\mathbf{1 , 2 , 3 , 4}$ & $\mathbf{5 , 6 , 7 , 8 , 9}$ & $\mathbf{1 0 , 1 1 , 1 2 , 1 3 , 1 4}$ & $\mathbf{1 5 , 1 6 , 1 7}$ \\
\hline Shape of cell & Short rod shape & Short rod shape & Short rod shape & Short rod shape \\
Motility & ++++ & +++++ & +++++ & +++ \\
Gram reaction & $\mathrm{G}-\mathrm{ve}$ & $\mathrm{G}-\mathrm{ve}$ & $\mathrm{G}-\mathrm{ve}$ & $\mathrm{G}-\mathrm{ve}$ \\
Sporulation & no spore & no spore & no spore & no spore \\
Brown pigment & ++++ & +++++ & +++++ & +++ \\
Fluorescent pigment & not produced & not produced & not produced & Not produced \\
\hline
\end{tabular}

$+=$ Positive reaction

- = Negative reaction

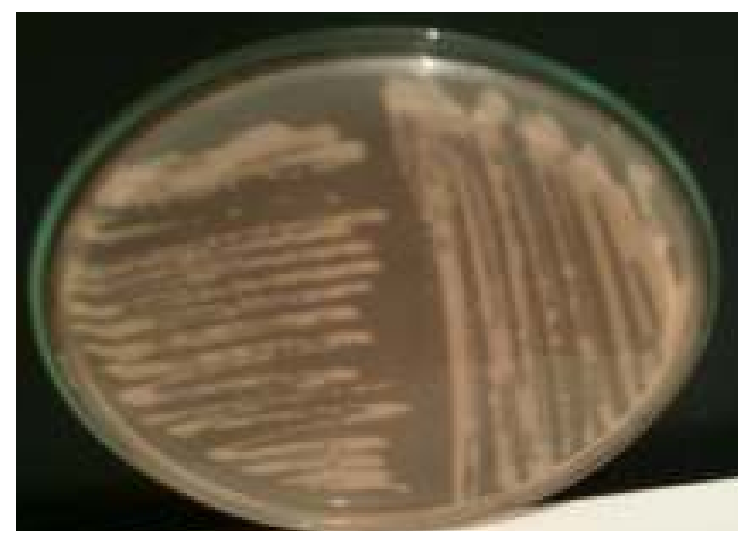

Fig. 1. Colony morphology of virulent isolate Ralstonia solanacearum on King's B medium

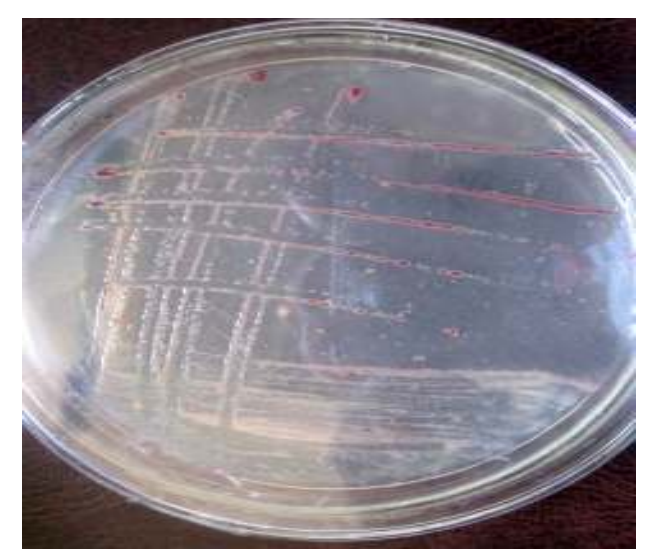

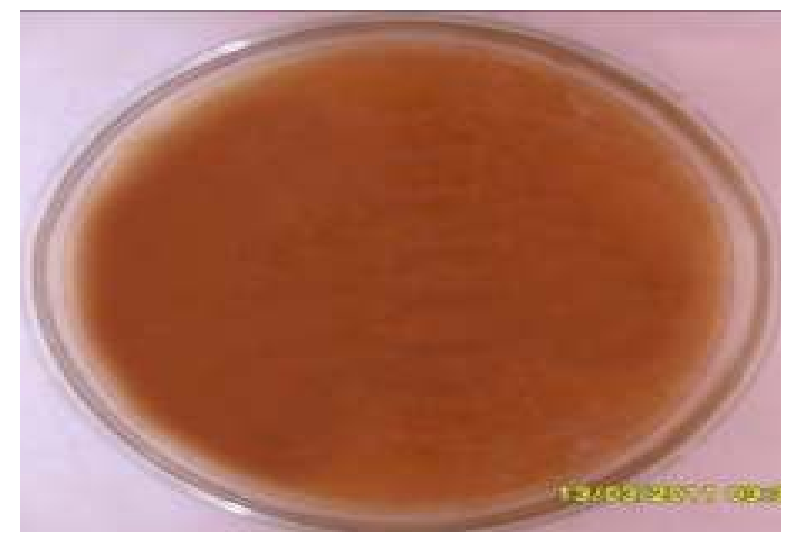

Fig. 2. Brown pigmentation of virulent Ralstonia solanacearum on King's B medium

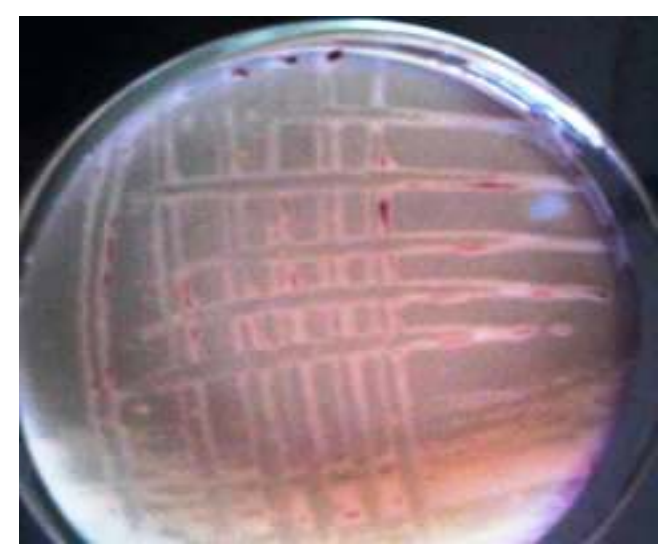

Fig. 3. Virulent colonies of Ralstonia solanacearum isolates on Tetrazolium chloride medium (TZC) 
The isolates were characterized physiologically and biochemically and results tabulated as seen in Table 4. All isolates were grown at $37^{\circ} \mathrm{C}$ and failed at $41^{\circ} \mathrm{C}$, strictly aerobic bacterium and positive for oxidase and catalase activities and Levan test (Schaad, 1980). They are denitrifying bacteria and were able to use citrate. They can hydrolyze of casein and urea but not starch. They do not show gelatin liquefaction, lecithin hydrolysis produced indol, arginine dihydrolase. These results are in accordance with those described by Holt et al. (1994). Like other gram negative bacteria, the isolates of $R$. solanacearum were able to develop blue color in Kovac's test by oxidizing the sugars.

Table 5 show that $R$. solanacearum isolates oxidized monosaccharides (glucose), disaccharides (maltose, lactose, and cellobiose) and did not oxidize sugar alcohols (sorbitol and mannitol) within 3-5 days. The oxidation reaction was indicating by the change of colour. The results revealed the change of colour blue to yellow indicating the oxidization of sugars by bacterial. The oxidation reaction was indicating by the change of colour. Therefore, all groups of $R$. solanacearum isolated have shown affiliation to race 3, biovar 2 as shown in Table 5. The differentiation of biovars of $R$. solanacearum based on the utilization of carbohydrates was reported previously by Hayward (1964), Tohamy et al. (2007) and Abd-Elrahim et al. (2015).

The races of R.solanacearum were identifyed by pathogenicity tests in host range such as potato and tomato. The result of the pathogenicity test in the greenhouse showed that, none of the group of $R$. solanacearum isolates was un able to cause wilt in inoculated tomato seedlings and potato plants indicating a narrow host range. Therefore, all isolates of $R$. solanacearum causing bacterial wilt of potato collected from three selected growing areas belong to race 3 . These results have agreed with Graham and Lloyd (1978) who they reported that tomato seedlings and potato plants have commonly been used as indicator plants. Five races have been described so far, but they differ in host range, geographical distribution and ability to survive under different environmental conditions (French, 1986). Patrice (2008) reported that, $R$. solanacearum was initially subdivided into races and biovars based on variability in host range. He added that five races have been identified within the species.
Torres (2001) stated that strains of $R$. solanacearum are grouped into five races according to the host or according to the use of selected properties. Balabel (2006) stated that potato brown rot, caused by $R$. solanacearum race 3 biovar 2, the so- called potato race, is the only strain in potato on Egypt and is a serious endemic disease in the Nile Delta, race1, however, could not be detected. Molecular analysis have confirmed that the Egyptian isolate confirm with those of phylotype II, sequevar 1.

\section{Identification of Ralstonia solanacearum by Polymerase Chain Reaction (PCR)}

Identification of $R$. solanacearum isolates to strain level/reference from different sources was confirmed using PCR technique, as illustrated in Fig. 4. Results of PCR technique of the highly virulent tuber T6 and water W11, showed that the two samples visualized specific 718 bp PCR product under UV light. PCR results indicated very close similarity without any variation among the two tested isolates. The positive control using $R$. solanacearum identified by the Brown Rot Project in Egypt sponsored this investigation, has confirmed that the two tested bacterial isolates are $R$. solanacearum. Several workers confirmed the identification of $R$. solanacearum using PCR (Pastrik et al., 2002; Tohamy et al., 2007; Mahdy et al., 2012; AbdElrahim et al. 2015).

\section{Effect of Adding Different Bio-control Agents on Potatoes Bacterial Wilt at Three Different Times}

Biological control studies were carried out in greenhouse with $P$. fluorescens, $B$. subtilis, $P$. aeruginosa and Trichoderma sp. Results indicated that the tested cultivars were highly susceptible to $R$. solanacearum $\mathrm{W} 11$ and T6 with score $100 \%$ of disease index compared to control plants.

The application of the tested bi-control organisms to $R$. solanacearum infected plants caused higher decrease in the disease index compared with control. The potential of the biocontrol agents in decreasing the disease in a descending order as $P$. fluorescens, B. subtilis, $P$. aeruginosa and Trichoderma sp. Potato cultivar Orchestra, Mustang and Nicola were less sensitive to disease progress with the isolates W11 than T6 strain under effect of such agents (Table 6). 
Zagazig J. Agric. Res., Vol. 44 No. (5) 2017

Table 4. Physiological and biochemical characteristics of pathogenic bacteria recovered

\begin{tabular}{|c|c|c|c|c|}
\hline \multirow[t]{2}{*}{ Character } & \multicolumn{4}{|c|}{ Source of bacterial isolates } \\
\hline & $\begin{array}{c}\text { Soil } \\
1,2,3,4\end{array}$ & $\begin{array}{c}\text { Tuber } \\
5,6,7,8,9\end{array}$ & $\begin{array}{c}\text { Water } \\
10,11,12,13,14\end{array}$ & $\begin{array}{c}\text { Weed } \\
15,16,17\end{array}$ \\
\hline Growth at $41^{\circ} \mathrm{C}$ & $-\ldots$ & $-\ldots$ & $\ldots$ & $-\ldots$ \\
\hline Kovac's test (Oxidase reaction) & ++++ & +++++ & +++++ & +++ \\
\hline Gelatin liquefaction & - - - - & - - - - & $-\ldots$ & -- \\
\hline Starch hydrolysis & $\ldots$ & $-\ldots$ & $-\ldots$ & $-\ldots$ \\
\hline Lecithin hydrolysis & - . - & $-\ldots$ & $-\ldots$ & - - - \\
\hline Denitrifaction & ++++ & +++++ & +++++ & +++ \\
\hline Casein hydrolysis & ++++ & +++++ & +++++ & +++ \\
\hline Urea hydrolysis & ++++ & +++++ & +++++ & +++ \\
\hline Growth in KCN & ++++ & +++++ & +++++ & +++ \\
\hline Citrate utilization & ++++ & +++++ & +++++ & +++ \\
\hline Catalase activity & ++++ & +++++ & +++++ & +++ \\
\hline Indol production & - - - - & - . - - & - . - - & -- \\
\hline КОН 3\% & ++++ & +++++ & +++++ & +++ \\
\hline Arginine dihydrolase & - . . & - - - - & - - - - & - . - \\
\hline Levan formation & ++++ & +++++ & +++++ & +++ \\
\hline
\end{tabular}

$+=$ Positive reaction

$-=$ Negative reaction

Table 5. Results of Ralstonia solanacearum biovar determination

\begin{tabular}{|c|c|c|c|c|c|c|}
\hline \multirow[t]{2}{*}{ Bacterial isolates } & \multicolumn{6}{|c|}{ Sugar sources } \\
\hline & Glucose & Maltose & Lactose & Cellobiose & Sorbitol & Mannitol \\
\hline Soil $1,2,3,4$ & ++++ & ++++ & ++++ & ++++ & $-\cdots$ & --- \\
\hline Tuber 5,6,7,8,9 & ++++ & ++++ & ++++ & +++++ & ---- & ---- \\
\hline Water $10,11,12,13,14$ & ++++ & ++++ & ++++ & +++++ & ---- & ---- \\
\hline Weeds 15,16,17 & +++ & +++ & +++ & +++ & - - - & \\
\hline
\end{tabular}

$+=$ Positive reaction $\quad-=$ Negative reaction

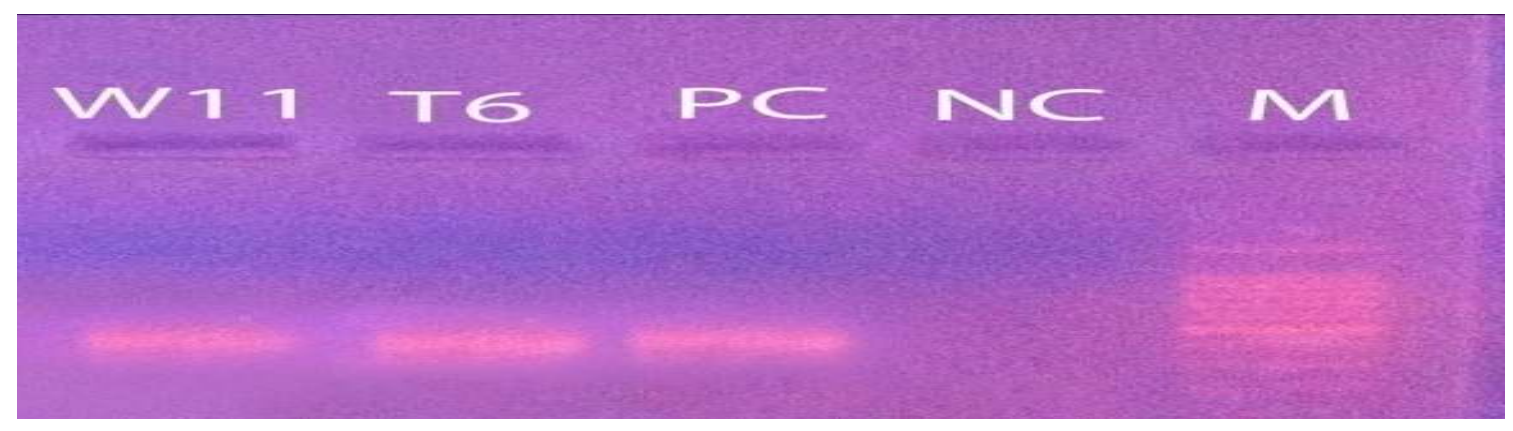

Fig. 4. PCR products amplified using (Oli-1) from genomic DNA of different two $R$. solanacearum isolates from different habitats. $\mathrm{PC}=$ positive control, $\mathrm{NC}=$ negative control, $\mathrm{M}=$ marker, T6 $=$ tuber isolate, $\mathrm{W} 11=$ water isolate 
Table 6. Effect of different bio-agents at different times using different cultivars of potato against. Ralstonia solanacearum W11 and T6 strains on disease index (\%)

\begin{tabular}{|c|c|c|c|c|c|c|c|}
\hline Treatment & Strain & & & Disease i & $\overline{\operatorname{dex}(\%)}$ & & \\
\hline Plant & & & & Cult & vars & & \\
\hline (-ve control) & & Orchest & & Musta & & Nico & \\
\hline & & 0.0 & & 0.0 & & 0.0 & \\
\hline Plant + & & & & Pathoge & strains & & \\
\hline pathogen & & & ater W11 & & $\mathrm{Tl}$ & uber T6 & \\
\hline & & & & Cult & vars & & \\
\hline & & Orchestra & Mustang & Nicola & Orchestra & Mustang & Nicola \\
\hline & & 100.0 & $100.0^{\circ}$ & 100.0 & 100.0 & $100.0^{\circ}$ & 100.0 \\
\hline Plant + bio- & & & & Cult & vars & & \\
\hline agents & & Orchestı & & Musta & & Nico & \\
\hline (+ve control) & $\begin{array}{l}\text { Pseudomonas } \\
\text { fluorescens }\end{array}$ & 0.0 & & 0.0 & & 0.0 & \\
\hline & $\begin{array}{l}\text { Bacillus } \\
\text { subtilis }\end{array}$ & 0.0 & & 0.0 & & 0.0 & \\
\hline & $\begin{array}{l}\text { Pseudomonas } \\
\text { aeruginosa }\end{array}$ & 0.0 & & 0.0 & & 0.0 & \\
\hline & Trichoderma sp. & 0.0 & & 0.0 & & 0.0 & \\
\hline
\end{tabular}

Plant + bio-

agents +

pathogen
Water strain W11 Tuber strain T6
Cultivars

\begin{tabular}{llcccccc} 
& & Orchestra & Mustang & Nicola & Orchestra & Mustang & Nicola \\
Before & Pseudomonas & 23.0 & 23.0 & 32.0 & 25.0 & 27.0 & 32.31 \\
After & fluorescens & 36.0 & 45.0 & 42.31 & 37.5 & 38.6 & 43.85 \\
Zero & & 24.0 & 26.6 & 27.3 & 33.3 & 28.0 & 30.3 \\
Before & Bacillus & 20.63 & 26.6 & 28.1 & 22.27 & 28.0 & 32.0 \\
After & subtilis & 35.0 & 40.88 & 45.1 & 38.0 & 50.0 & 51.5 \\
Zero & & 22.33 & 26.1 & 37.0 & 24.0 & 42.0 & 40.0 \\
Before & Pseudomonas & 27.1 & 32.0 & 29.0 & 37.8 & 44.0 & 49.0 \\
After & aeruginosa & 37.0 & 38.9 & 42.0 & 43.0 & 65.0 & 52.0 \\
Zero & & 30.66 & 37.14 & 43.0 & 39.0 & 38.0 & 50.0 \\
Before & Trichoderma sp. & 55.0 & 60.0 & 60.0 & 50.0 & 60.0 & 60.0 \\
After & & 70.0 & 74.0 & 80.5 & 72.5 & 73.5 & 79.8 \\
Zero & & 59.0 & 64.0 & 64.5 & 56.0 & 64.2 & 76.65 \\
\hline
\end{tabular}

$\begin{array}{lcc}\text { LSD 0.05 C } & 0.44 & 1.03 \\ \text { LSD 0.05 B } & 0.55 & 0.72 \\ \text { LSD 0.05 C } \times \text { B } & 0.95 & 1.25 \\ \text { LSD 0.05 T } & 0.37 & 0.37 \\ \text { LSD 0.05 C } \times \text { T } & 0.65 & 0.64 \\ \text { LSD 0.05 B } \times \text { T } & 1.24 & 1.33 \\ \text { LSD 0.05 C } \times \text { B } \times \text { T } & 2.15 & 2.12 \\ \text { C }=\text { cultivars } \quad \text { B=Bio-agents } & \text { T }=\text { Treatments }\end{array}$


Soil treated with the tested agents one week before planting or preplanting decreased disease index of the three potato cultivars compared to post planting or at zero time of experimentation. Nguyen et al. (2011) reported that disease severity was high when both antagonist and pathogen were introduced simultaneously compared to antagonist supplemented prior the pathogen. The increased disease severity may be attributed to the chemotactic effect of the rizosphere on the pathogen, hence greater inoculum density before reassemble establishment of the antagonist in the root zone appeared to be the opportunity available for the pathogen to easily invade the root cells in the logically, the suppression must occur before infection start in situ.

Potato treated with Trichoderma spp. one week after planting showed the highest wilt index recording $70.0,74.0$ and $80.5 \%$ in case of $R$. solanacearum $\mathrm{W} 11$ and $72.5,73.5$ and $79.8 .0 \%$ of disease index in case of $R$. solanacearum T6, on cv. Orchestra, Mustang and Nicola, respectively (Table 6). Similar results were obtained by, Atia et al. (2010). Rosyidah et al. (2013) reported that the single application of $P$. fluorescens or combined application of Streptomyces spp. and Trichoderma viride + Streptomyces spp. was capable reducing disease incidence, reducing disease intensity and reducing the population $R$. solanacearum. Nguyen et al. (2011) declared that disease severity varied with antagonist and time of application. The disease severity decreased when antagonists were applied one week prior to transplanting tomato seedlings. Suppression mechanisms are typically attributed to the antibacterial metabolites produced by biological control agents or those present in natural products; however, the number of studies related to host resistance to the pathogen is increasing (Yuliar and Toyota, 2015). It is worth mentioning that the tested fungal bioagent was less effective than the bacterial bioagent in the decreasing of wilt disease index.

\section{REFERENCES}

Abd-Elrahim, R., M.M. Atia, M.R.A. Tohamy and N.M. El-Sarkassy (2015). Isolation and identification Ralstonia solanacearum from different sources and locations. Zagazig J. Plant Pathol. and Prot., 42: 269-281.

Ahmed, N.N., I. Rashidul, M.A. Hossain, M.B. Meah and M.M. Hossain (2013). Determination of races and biovars of Ralstonia solanacearum causing bacterial wilt disease of potato. J. Agric. Sci., 5 (6): 86-93.

Algam, S.A., G.L.B. Xie, S. Yu, T. Su and J. Larsen (2010). Effects of Paenibacillus strains and chitosan on plant growth promotion and control of Ralstonia wilt in tomato. Eur. J. Pl. Pathol., 92 (3): 593- 600.

Atia, M.M., M.M.A. Tohamy, F.F. Gabriel and H. A. Mater (2010). Integrated management of potato brown rot. Proc.of the Sixth Int. Conf. Susation Agric., Fayoum Univ., 275294.

Balabel, N.M. (2006). Persistence of Ralstonia solanacearum (Syn. Pseudomonas solanacearum) in different habitats. Ph.D. Thesis, Fac. Agric., Ain Shams Univ.

Barea, J.M. and P. Jeffries (1995). Arbuscular Mycorrhizas in Sustainable Soil Plant Systems. In: Mycorrhiza Structure, Function, Molecular Biology and Biotechnology, Hock, B. and A. Varma (Eds.). Springer, Heidelberg, 521-559.

Champoiseau, P.G., J.B. Jones, T.M. Momol, P. Ji, C. Allen, D.J. Norman, C. Harmon, S.A. Miller, T. Schubert, D. Bell, J.P. Floyd, D. Kaplan, R. Bulluck, K. Smith and K. Cardwell (2010). Ralstonia solanacearum race 3 biovar 2 causing brown rot of potato, bacterial wilt of tomato and southern wilt of geranium. Available at http://plantpath. ifas. ufl.edu/rsol/NRI_Project/ Project summary. html, Ame.Phytopathol. Soc.,Madison, WI.

Cochran, W.C and G.N. Cox (1957). Experiment Design $2^{\text {nd }}$ Ed., 26. Wiley and Sons. Inc., N.Y.

Denny, T.P. (2006). Plant Pathogenic Ralstonia species. In: Plant Associated Bacteria Gnanamanickam, S.S. (Ed.) Springer Publishing, Dordrecht, the Netherland, 573644.

El-Habbaa, G.M., F.G. Mohammed and M.S. Youssef (2016). Detection and virulence of 
Ralstonia solanacearum the causal of potato brown rot disease. Int. J. Sci. and Eng. Res., 7: 1209-1217.

Elphinstone, J.G., J.K. Hennessey, J.K. Wilson and D.E. Stead (1996). Sensitivity of different methods for the detection of Pseudomonas solanacearum in potato tuber extracts. Bulletin OEPP/EPPO Bulletin, 26: 663-678.

Engelbrecht, M.C. (1994). Modification of a selective medium for the isolation and quantification of Pseudomonas solanacearum. ACIAR Bacterial Wilt Newsletter, 10: 3-5.

French, E.R. (1986). Interaction between isolates of Pseudomonas solanacearum its hosts and the environment. In G. L. Persley (Ed.), Bacterial wilt disease in Asia and the South Pacific. Proc. Int. Workshop Held at PCARD, Los Banos, the Philippines, 99-104.

George, M. and E.D. Garrity (2012). Bergey's Manual of systemic Bacteriology (in English) 4 ( $2^{\text {nd }}$ Ed.). New York: Springer. ISBN 978-0-387-95043-3, 1750.

Graham, J. and A.B. Lloyd (1978): An improved indicator plant method for the detection of Pseudomonas solanacearum race 3 in soil. Plant Disease Reporter, 62: 35-37.

Grover, A., S.K. Chakrabarti, W. Azmi and S.M.P. Khurana (2012). Rapid method for isolation of PCR amplifiable genomic DNA of Ralstonia solanacearum infested in potato tubers. Adv. Microbiol., 2: 441-446.

Hayward, A. C. (1964). Characteristics of Pseudomonas solanacearum. J. Appl. Bacteriol., 27(2): 265-277.

Hayward, A.C. (1991). Biology and Epidemiology of Bacterial Wilt caused by Pseudomonas solanacearum. Ann. Rev. Phytopathol., 29: 65-87.

Holt, J.G., N.R. Krieg, P.H.A. Sneath, J.T. Staley and S.T. Williams (1994). In: Bergy's Manual of Determinative Bacteriology. $9^{\text {th }}$ Ed. Williams and wilkins Pub Md USA.

Janse, J.D. (1988). A detection method for Pseudomonas solanacearum in symptomless potato tubers and some data on its sensitivity and specificity. Bulletin OEPP/EPPO Bulletin, 18: 343-351.

Jenkins, Jr.S.F., D.J. Morton and P.D. Dukes (1967). Comparison of techniques for the detection of Pseudomonas solanacearum in artificially infested soils. Phytopathol., 57: 25-27.

Kemp, J. and L. Sequeira (1983). Biological control of bacterial wilt of potatoes: Attempst to induce resistance by treating tubers with bacteria. Plant Dis., 67: 499-503.

Koneman, W.E., D.S. Allen, V.R. Dowell and M.H. Somners (1983). Color Atlas and Textbook of Diagnostic Microbiology. $2^{\text {nd }}$ Ed., Philadelphia. St. Louis, London. Sao Poulo, New York, Sydney.

Mahdy, A.M.M., F.G. El-Habbaa and M.A.A. Badr (2012). Virulence of Ralstonia solanacearum the causal of potato brown rot disease under Egyptian conditions. Ann. Agric. Sci., Moshtohor, 50 (1):59- 67.

Naser, A., F. Chemeda and H. Yaynu (2008). Evaluation of bacterial antagonists for their potential to bioprotect potato (Solanum tuberosum) against bacterial wilt (Ralstonia solanacearum). Biol Control., 47: 282-288.

Nguyen, M.T., S.L. Ranamukhaarachchi and D.B. Hannaway (2011). Efficacy of antagonist strains of Bacillus megaterium, Enterobacter cloacae, Pichia Guilliermondii and Candida ethanolica against bacterial wilt disease of tomato. J. Phytol., 3(2): 01-10.

Nurbaya, R.M., D. Kuswinanti and T. Baharuddin (2011). Combined effect of isolate antagonistic bacteria to bacterial wilt disease (Ralstonia solanacearum) raising the potato crop aeroponics (in Indonesia). http:// www. peipfi-komdasulsel. org.

Pastrik, K.H., J.G. Elphinstone and R. Pukall (2002). Sequence analysis and detection of Ralstonia solanacearum by multiplex PCR amplification of 16s- $23 \mathrm{~s}$ ribosomal intergenic spacer region with internal positive control. European J. Pl. Pathol., 108: 831-842.

Patrice, G. (2008). R. solanacearum race 3 biovar 2: detection, exclusion and analysis of 
a Select Agent Educational modules. The United States Dept. Agric.-Nat. Res. Initiative Program, 1-4.

Rosyidah, A., T. Wardiyati, A. Abadi and M.D. Maghfoer (2013). Enhancement in effectiveness of antagonistic microbes by means of microbial combination to control Ralstonia solanacearum on potato planted in middle latitude. J. Agrivita, 35 (2): 174-183.

Saad, M.M. (2011). Phytopathological studies on the causal agent of potato brown rot. M.Sc. Thesis Agric. Sci., Fac. Agric., Cairo Univ., 103-110.

Sabet, K.A. (1961). The occurrence of bacterial wilt of potatoes caused by Pseudomonas solanacearum (EF Smith) EF. Sm. in Egypt. Min. of Agric., Extension Dept., Tech. Bull., 112: 116-119.

Seal, S.E., L.A. Jackson, J.P.W. Young and M.J. Daniels (1993). Differentiation of Pseudomonas solanacearum, Pseudomonas syzygii, Pseudomonas pickettii and the blood disease bacterium by partial $16 \mathrm{~S}$ rRNA sequencing; construction of oligonucleotide primers for sensitive detection by polymerase chain reaction. J. Gen. Microbiol., 139: 1587-1594.

Schaad, N.W. (1980). Laboratory guide for the identification of plant pathogenic bacteria. Ame. Phytopathol Soc St Paul Minn., 28-45.

Soesanto, L., E. Mugiastuti and M. Wachjadi, (2013). Ability test of several antagonists to control potato bacterial wilt in the field. J. Biotech. Biodiver., 2:19-26.

Suslow, T.V., M.N. Schroth and M.H. Isaka (1982). Application of rapid method for Gram differentiation of plant pathogenic and saprophytic bacteria without staining. Phytopathol., 72: 917-918.

Sulistyo, M.A.B., R. Anis, S.R. Yekti and S. Bambang (2012). The influence of organic matter (chicken manure and Paitan) and
Trichoderma harzianum for controlling bacterial wilt on potatoes. (in Indonesia). J. Primordia, 8 (2):144-153.

Tohamy, M.R.A., M.M.M. Atia, F. Faiza and H.A. Mater (2007). Identification of Ralstonia solanacearum isolated from potato tubers, weeds, water and soil in Egypt. Zagazig J. Agric. Res, 34(3):445-462.

Torres, H. (2001). Thecaphora smut. In: Compendium of Potato Diseases. $2^{\text {nd }}$ Ed. Stevenson WR, Loria R, Franc GD, Weingartner DP, eds. Saint Paul, Minnesota, USA: APS Press, 43-44.

Van der Wolf, J.M., P.J. Bekkum van, J.D. Elsas van, E.H. Nijhuis, S.G.C. Vriend and M.A. Ruissen (1998). Immunofluorescence colony-staining and selective enrichment in liquid medium for studying the population dynamics of Ralstonia (Pseudomonas) solanacearum (race 3) in soil. EPPO Bull., 28: 71-79.

Wenneker, M., M.S.W. Verdel, A.R. Van Beuningen, J.H.J. Derks and J.D. Janse (1999). Ralstonia (Pseudomonas) solanacearum race 3 (biovar 2) in surface water and natural weed hosts: first report on stinging nettle (Urtica dioica). Europ. J. Pl. Pathol., 105: 307-315.

Yabuuchi, E., V.Y. Kosako, I. Yano, H. Hotta and Y. Nishiuchi (1995). Transfer of two Burkholderia and an Alcaligenes species to Ralstonia gen. nov.: proposal of Ralstonia picketii (Ralston, Palleroni and Doudoroff 1973) comb. nov., $R$. solanacearum (Smith 1896) comb. nov. and Ralstonia eutropha (Davis 1969) comb. Nov. Microbiol. Immunol., 39: 897-904.

Yuliar; N.Y.A. and K. Toyota (2015). Recent trends in control methods for bacterial wilt diseases caused by Ralstonia solanacearum. Microbes Environ., 30 (1): 1-11. 


\title{
المكافحة الحيوية للابول البكتيرى على البطاطس المتسبب عن رالستونيا سولاناسيرم المعزولة من
}

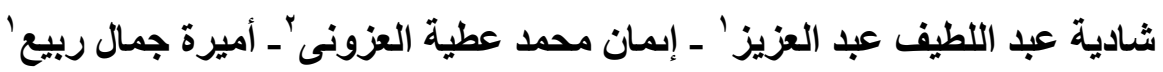

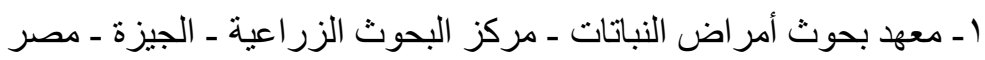

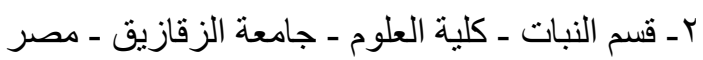

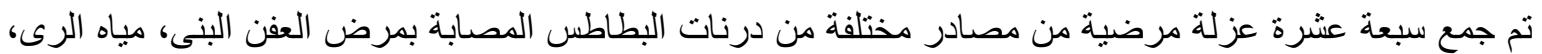

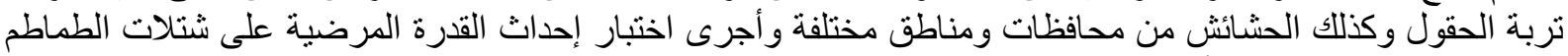

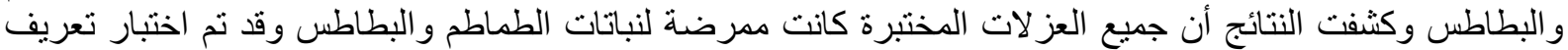

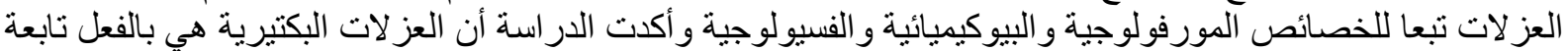

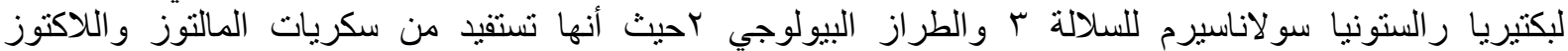

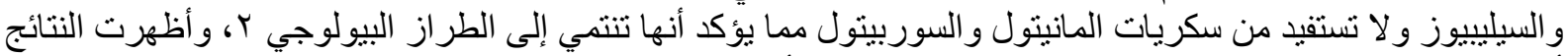

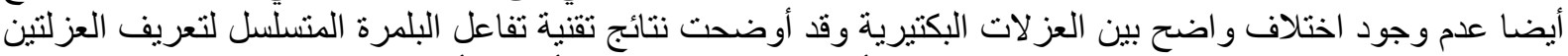

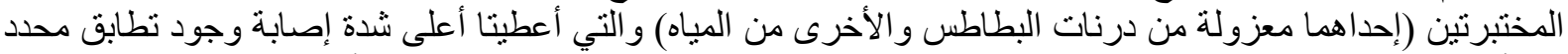

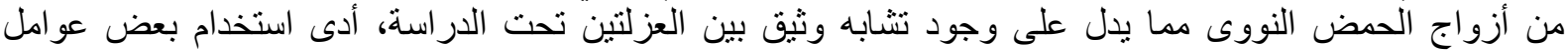

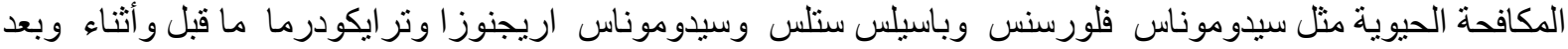

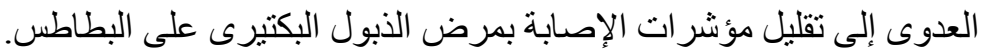

أستاذ أمر اض النبات ـ مركز البحوث الزر اعية. أستاذ ورئيس قسم أمر اض النبات ـ كلية الزر اعة - جامعة الزقازية الزيق. 